\title{
Knowledge Management, Intellectual Capital, And Performance Of Branch Office Of State-Owned Banks
}

\author{
Hady Siti Hadijah \\ Fakultas Pendidikan Ekonomidan Bisnis Universitas Pendidikan Indonesia \\ hady@upi.edu
}

\begin{abstract}
The goal of this research is to determineif intellectual capital could mediate the influence of knowledge management on the branch performance offices of state-owned banks. If we compare to the ASEAN banks, the performance of state-owned banks is weak, especially in the case of operational cost efficiency depressing the potential for large profits. The low level of performance cannotbeseparatedfrom of the low performance of branch offices. BI's expectation as stipulated in the BI Regulation of 2010 is that the banking sector should perform the maximum role of branch offices because if the management of branch offices understandknow more than head officedoes. The improvement in knowledge management should be made by state-owned banks at branch offices.Beside, it is necessary that aggregation of all knowledge and employee competence that allows companies to gain competitive advantage. In my research, the method of research used is explanatory survey. Structural Equation Modeling (SEM) using LISREL was chosen to test the hypothesis.152 pieces of sample were taken from the whole stateowned banksoffices in West Java. The focus of the assessment is the branch officees of state-owned banks located in the region of West Java because the industry's contribution in the region to GRDP is relatively large. My research concluded that the effect of Knowledge Management on Intellectual Capital was significant. The effect of Knowledge Management and Intellectual Capital on the performance of each Branch Office is significant. In this case intellectual capital played a role in mediating the effect of Knowledge Management to the Branch performance Offices of state-owned banks in West Java. The Branch offices conducting knowledge management continuously resulted the good intellectual capital, which would strengthen the role of knowledge management in improving the branch performance.
\end{abstract}

Keywords: Knowledge Management, Intellectual Capital, Performance of Bank Branch Offices

\section{INTRODUCTION}

On a national scale, state-owned banks have a fairly good positioning at this time. However, the enforcement agreement the AEC industry of banking services, the severity level of competition will begin to be felt state-owned banks, especially the competition that comes from the banks of Singapore, for example DBS in the year of being declared as e the best bank in Asia Pacific 2014 version of Global Finance. This award was arecognition that the Singapore bank had the right positioning strategy. From the best banks in the ASEAN region emerged as the best banks in the Asia Pacific region. If the red plate bank want to be strong in domestically, then there are things that need attention. First, the ability of state-owned banks to collect third party funds.Supported by a large 
population and potential of Indonesia as a country with great economic power should have state-owned banks having ability to play the role of the intermediary function as collector and distributor of funds. But the fact is not as expected.

The DBS bank case is a description of how strong it will be if this bank is free to operate in Indonesia, one country in Southeast Asia with the largest population of around two hundred and fifty million people with the widest area. Apart from the problem of the total strength of the banking assets of the Singapore bank, there are things that need to get attention from state-owned banksif they want to strengthen their position in their own country. The first problem is the ability of state-owned banks to collect third party funds. With a large population, supported by the potential of Indonesia as a country with a large economic power, state-owned banks should be able to take on the role of intermediary functions as fund collectors and distributors. One example is that some Indonesians who have large funds prefer to save their funds in other countries, including in Singapore. This condition needs great attention from state-owned banks to be able to ensure that their banks have greater added value compared to favorite banks in other countries in the ASEAN region. State-owned banks through their bank branch offices are the spearhead of banks scattered in various regions should be able to attract the public to save funds in their branch offices as the primary choice. The second problem, the high inefficiency of operational costs can reduce the potential for large net income. The world's best banks have the power to control operational efficiency. The realization of operational costs adjusted to the workload of bank employees will support the bank in achieving high income. So far, state-owned banks are struggling with high interest rates, while international banks are playing at low interest rates. Branch offices and branch offices of state-owned banks must control the level of efficiency to remain high.

One of the policies to improve the intermediary function operating globally is to maximize the role of branch offices and provides high flexibility to branch offices because branch offices are units of banks that serve community transactions and provide a full range of bank services compared to units. In addition, branch offices have better understanding on local potential than regional offices or head offices. In My research I focused on the branch office of state-owned banks located in West Java considering the contribution of industry in the region to GRDP is larger compared to other provinces (BPS, 2014) so that the bank's function as an intermediary is more necessary.

I do not only payatteention to the resources of state-owned bankson the side of tangible resources but also in intangible resources. I define the intangible resources as intellectual capital (Bontis, 2000). After being able to create value and performance, the role of intellectual capital becomes vital. The fact shows that state-owned banks' intellectual capital is still unsatisfactory. Another necessary factor that is knowledge management.The increasing level of interest to the real sector makethebankers realize that they need competent human resources in every sector. In return, this opens the practice of moving the competent human resoursec from one bank to the other bank. It looks like an open door for hijacking employee from one bank. In this case, knowledge management is necessary to keep and produce more the important human resources.

In this study, the object discussed was the branch office of the bank led by the branch manager, considering the branch manager knew more about local potential changing real sector in his working area, ad was more sensitive to nearby resources. Banks with should give high attention to the existin. 
The writing of this paper aimed at presenting the effect of whether Knowledge Management on Intellectual Capital, the effect Knowledge Management and Intellectual Capital and the mediating role of Intellectual Capital promote the effect of Knowledge Management on Banks Performance

\section{THEORETICAL REVIEW}

Knowledge Management. The banking services industry is currently faced with increasing competition, both on a national and regional scale, in this case Southeast Asia. One of the important roles is the use of knowledge management to strengthen bank competition in terms of the use of knowledge as a strategic resource. An effective way needs to be developed by the organization to study the environment and carry out strategic decisions so that they can take advantage of the opportunities and face the threats that occur. Effective ways need to be developed by supporting the use of information technology and knowledge management. In other words, the organization should study the weaknesses, strengths of competitors, and learn about the desires and needs of consumers by increasing innovation capabilities, technology exploitation, and investing in knowledge-based knowledge and HR processes.

It is realized that knowledge that is originally owned by individuals is transformed into the property of the organization. Organizations must facilitate, support, and stimulate individual knowledge into organizational knowledge. The process of creating knowledge in an organization is a process of creating and reinforcing pre-existing knowledge created by individuals and knowledge that crystallizes and connects them to the organization's knowledge system. The knowledge creation process is carried out through knowledge conversion which consists of four models namely socialization, externalization, combination, and internalization known as the SECI model in knowledge management (Nonaka and Takeuchi, 1995).

Understanding Knowledge Management (Knowledge Management) depends on the way the organization creates and utilizes that knowledge. As a management function, Knowledge Management is responsible for the selection, implementation, and evaluation of knowledge strategies oriented to the way the organization handles internal and external knowledge of the organization in order to improve organizational performance (Gonzales et. Al., 2014). In practice, knowledge management is used as a tool to increase intellectual capital as an intangible asset, which will guarantee tangible assets in the form of financial success in the future (Pasher, 2011).

The explanation above provides an explanation that knowledge management is a series of activities carried out by an organization to maintain existing knowledge and create new knowledge that is up-to-date through the integration of people, processes and technologies to add value to intangible assets that have an impact on improving organizational performance. The series of activities were carried out by applying the socialization, externalization, combination and internalization (SECI) models.

Intellectual Capital. Intellectual capital is a superior resource for creating economic wealth. Intangible assets such as land, buildings, machinery and equipment continue to be important factors in the production of both goods and services. However, its relative importance has diminished as the importance of intangible assets, namely knowledgebased assets has increased its role. Rafiee et.al.(2015) views that intellectual capital is 
knowledge that can be converted into value. Intellectual capital is an aggregation of all employee knowledge and competencies that allows the organization to gain competitive advantage.

Onyekwelu (2017) revealed three elements of intellectual capital proposed by Edvinsson\& Sullivan, Sveiby, and Stewart, namely intellectual capital that is inherent in human beings, attached to the organization, and related to external parties. Intellectual capital inherent in humans is known as human capital (employee competence) is the mastery of knowledge, technology, and innovation by human resources owned by the organization in an effort to achieve goals. From the organizational point of view, Intellectual capital is known as structural capital (organizational capital or internal structure). It is the company's ability to fulfill the routine process to produce optimal company performance. From point of view of the company's relationship with external parties known as relational capital (customer capital). It is the strength of the organization because it has a harmonious relationship with parties outside the company or with existing organizational environmental resources. These three elements will function if each other correlates. In this study what is meant by human capital includes the mastery of knowledge and skills about finance and banking that are needed now and in the future. Its structural capital includes the availability of SOPs (in addition to the service quality SOP), IT availability, and service quality. Finally, relational capital includes a harmonious relationship with potential customers and potential customers. (Salemi, 2014; Petriaet al.2015; Hughes, 2013; Al Musali, 2014; Onyekwelu, 2017; Andreeva\&Garanina, 2017).

Bank Performance. Organizational performance can be defined as the organization's ability to achieve its goals by using resources efficiently and effectively (Onyekwelu et.al, 2017; Andreeva\&Garanina, 2017). With reference to banking activities, the performance of branch offices is the result achieved by the bank in its operations, namely concerning aspects of fund collection and distribution, income, operational efficiency, and customer loyalty. Collection (third party fund raising) and fund channeling are the main activities of the bank as an institution that has an intermediary function between fund owners and users of funds. Practically, efficiency is very important in showing bank performance. Profit is one of several ways to increase banking capitalization (Al Musali et.al, 2014; Gigante, 2013). The last is customer loyalty which is shown through the growth of the number of customers which is a relation of the achievements of a bank.

Especially for branch offices and sub-branch offices of state-owned banks, there are five performance indicators that must be achieved, namely third party funds (demand deposits, deposits and savings), lending, revenue, operational efficiency and customer loyalty as measured by the small number of complaints and growth in the number of customers.

Effect of Knowledge Management on Intellectual Capital.Knowledge management can be defined a tool to increase intellectual capital which in turn guarantees future financial success (Pasher, 2011). Knowledge management helps in planning, organizing, and controlling people, processes and systems within the organization in order to ensure that the related knowledge assets can continue improved and used effectively (Rajesh et. al., 2011). Thus knowledge management has an influence on intellectual capital (Rafiee et.al, 2015; Nazem, 2012; Daud and Yusof, 2011). It can be concluded that to increase the 
effectiveness of intellectual capital with good valueadded. It requires continuous application of knowledge management.

From the description above, the first research hypothesis (H1) can be formulated as follows: Knowledge Management affect the Intellectual Capital.

Effect of Intellectual Capital on Performance.Onyekweluet.al (2017) and Andreeva\&Garanina (2017) research, stated that three dimensions of intellectual capital (human, structural, and customer / relational) which are interrelated affect the organizational performance positively. The very competent employeesucturalcapital, in order to (human capital) understand customer needs. They can mobilize customer capital in effective ways. In return, this affect structural capital, in order to promote business performance. Furthermore, intellectual capital can be defined as the economic value of the three categories of intangible assets of an organization that include human resources, organizational capital, and social capital collectively contributing to improving organizational performance (Al Musali, 2014; Gigante, 2013; Zehri, et .al. 2012). The three components of intellectual capital will have a significant influence on organizational performance provided there is a link between each component. Thus from the results of the research above, wecan see that there is an influence of the variable intellectual capital on the performance variable.

From the description above, the second research hypothesis $(\mathrm{H} 2)$ can be formulated as follows: Intellectual capital has an influence on performance.

Effect of Knowledge Management on Performance. Nonaka used the SECI matrix as a dimension of knowledge management argues that the success of many companies depends on their ability to create in new organizational knowledge through the transformation of tacit and explicit knowledge at three levels, namely individuals, groups and organizations. Organizational performance will increase through learning with a system that integrates people, processes and technology (Wang, 2011).

Knowledge management is a process that transforms individual knowledge into organizational knowledge (Rasula, 2012). Acquisition, application and protection of knowledge is significantly related to organizational performance (Mills and Smith, 2011). The existence of knowledge management leads to the development of new ideas, new products, and also new ways that lead to improved organizational performance (Mahapa, 2013). From the results can be concluded that knowledge management promote the performance of an organization.

From the description above, the third research hypothesis (H3) could be formulated as follows: Knowledge Management has an influence on Performance.

Influence of Knowledge Management on Performance Through Intellectual Capital. Salemiet.al (2014) showed that knowledge management has an indirect effect on business performance on the banking industry in Iran. Knowledge management has an influence on business performance. Intellectual capital as a mediator between knowledge management processes performance. The knowledge management process contributes positively to performance, but the inclusion of intellectual capital with its dimensions as a mediator helps improve performance, but the inclusion capital with its dimensions as a mediator helps improve performance. Thus, to be able to improve performance, banks need to focus on the knowledge management and intellectual capital. 
From the description above, the fourth research hypothesis (H4) could be formulated as follows: Knowledge management has an influence on the performance of banks through intellectual capital.

Based on the description of causal between the variables above can be seen in the Figure Research Model.

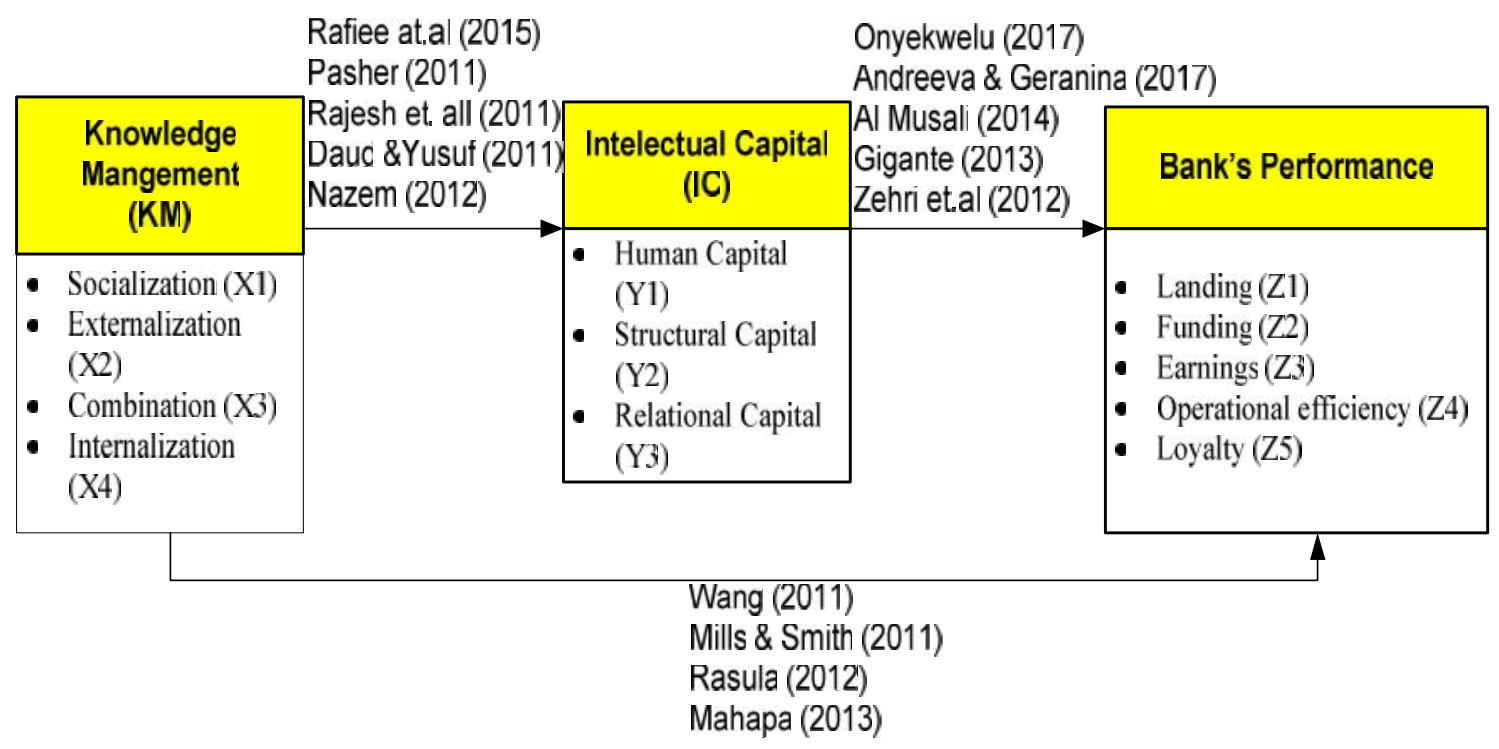

Fig. Research Model

\section{METHOD}

This study used descriptive survey method and explanatory survey method. This research was descriptive and verfative. Hypothesis testing was done through Structural Equation Model (SEM) using LISREL software. Measurement model analysis used was Confirmatory Factor Analysis (CFA). According to Hair et. al. (2006) CFA was used to find out if the indicators really could explain a construct. The criteria used for the validity test were t-value $96 \geq 1.96$, Standard Loading Factor (SLF) $\geq 0.5$ and for reliability was Construct Reliability (CR) 70.7 and Variance Extracted (VE) $\geq 0.70$. Construct Reliability (C-R) was obtained through the formula:

Construct Reliability $=\frac{(\text { sstandardized loading })^{\mathbf{z}}}{(\Sigma \text { standardized loading })^{\mathbf{2}}+\Sigma \varepsilon_{j}}$

and Variance Extracted (V-E) was obtained through the formula:

Construct Reliability $=\frac{(\text { standardized loading })^{\mathbf{z}}}{\Sigma(\text { standardized load ing })^{2}+\Sigma \varepsilon_{j}}$

Analysis of the suitability test used a measure of suitability or Goodness of Fit (GoF). The criteria used as a measure of suitability are chi square, CFI (Comparative Fit Index), GFI (Goodness of Fit Index), and RMSEA (Root Mean Square Error of Approximation) to test the suitability between models and data. The population was all branch offices (KC) and sub-branch offices (KCP) of state-owned enterprises in West Java Province with a size of 609 units. The sample used was 152 branch offices, according to 
the recommendations suggested by Hair et. al. (2006) which is 5 times the number of model parameters.Data collection techniques carried out by using three methods: literature study, field study through interviews, closed questionnaire using a Likert scale where according to Sekaran (2006) a Likert scale is an interval scale. To test the validity of the instrument using the correlation coefficient and reliability testing using the Cronbach Alpha coefficient formula.

\section{RESULTS AND DISCUSSION}

Instrument Validity and Reliability Test.The research questionnaire consisting of 21 items distributed to collect data in this study had been tested for validity and reliability where the item statement had a validity index $\geq 0.30$ and reliability $\geq 0.70$.

Results of Structural Equation Modeling (SEM) Analysis.In testing the hypothesis the author used Structural Equation Modeling (SEM) with the help of the Lisrel 8.8 program. Complete analysis results can be seen in the Complete Structural Model Figure.

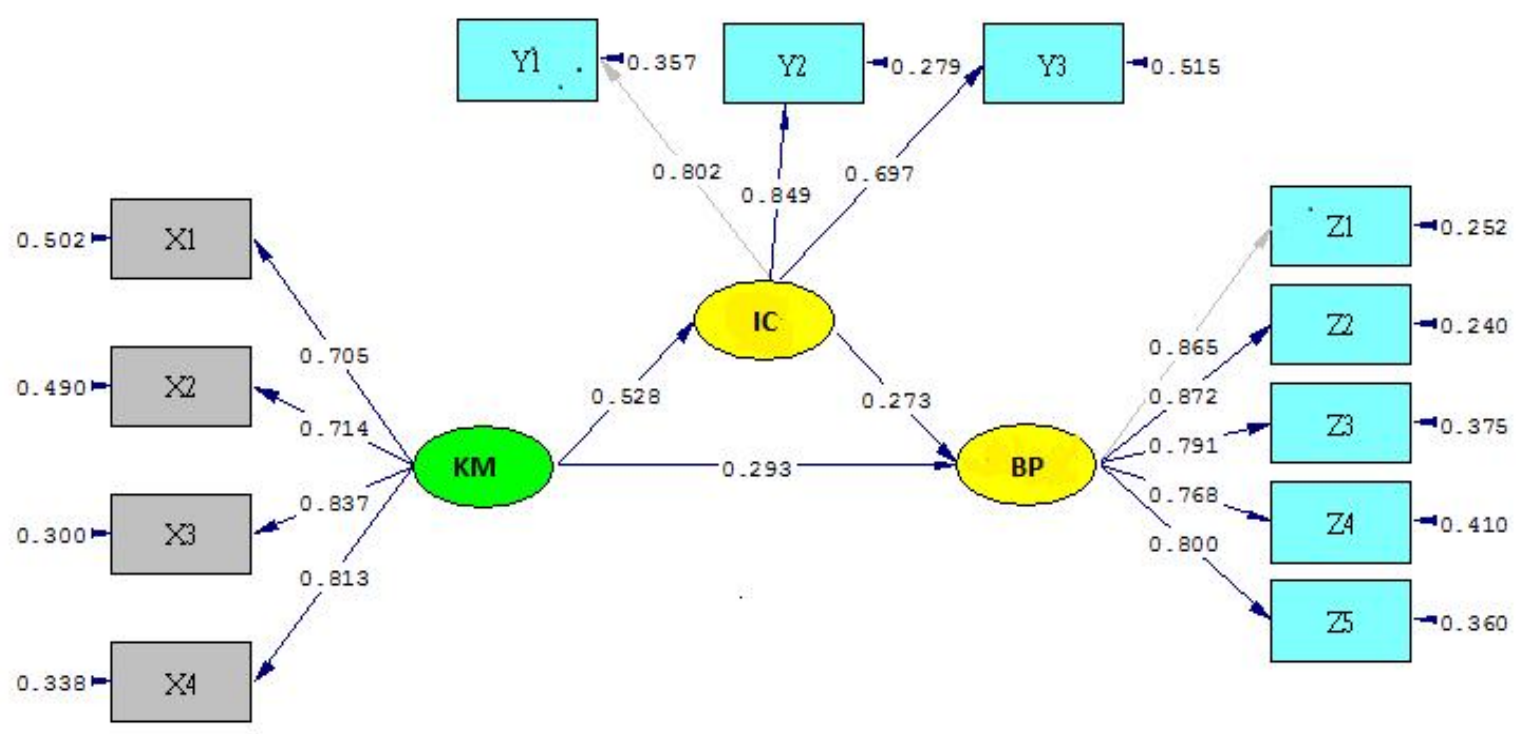

Chi-Square $=64.25, \mathrm{df}=51, \mathrm{P}-\mathrm{value}=0.10062, \mathrm{RMSEA}=0.041$

Fig. Complete Structural Model

Model Suitability Analysis (Goodness-of-Fit).Based on the results of the assessment of goodness of fit, the overall model shown in the Complete Structural Model Figure above meets the criteria of the fit model. The chi-square model value of 64.25 was below the chisquare table for 51 degrees of freedom at a significant level of 5\% of 68.666. The probability value of 0.10062 is greater than 0.05 . The RMSEA value was 0.041 less than 0.05 and the NFI Value Value, CFI, RFI, GFI above 0.9. CMIN / DF was 1.2599 below 2.00. Thus, the research model used could be accepted. 


\section{Measurement Model Analysis}

Table.1 Loding Factors Results for Measurement and Latent Variables

\begin{tabular}{|c|c|c|c|c|c|}
\hline $\begin{array}{l}\text { Measurement and } \\
\text { Latent Variables }\end{array}$ & $\begin{array}{l}\text { Loding } \\
\text { Factor } \\
\text { Know }\end{array}$ & $\begin{array}{c}\mathrm{t}_{\text {count }} \\
\text { edge Mar }\end{array}$ & agement & $\begin{array}{c}\text { Eror } \\
\text { Variance }\end{array}$ & \\
\hline Socialization & 0,705 & 11,155 & 0,4976 & $\mathbf{0 , 5 0 2}$ & $\mathrm{C}-\mathrm{R}=\mathbf{0 , 8 5 2}$ \\
\hline Externalization & 0,714 & 9,636 & 0,5096 & 0,409 & $\mathrm{~V}-\mathrm{E}=\mathbf{0 , 5 9 2}$ \\
\hline Combination & 0,837 & 10,970 & 0,7002 & 0,300 & \\
\hline Internalization & 0,813 & 11,898 & 0,6617 & 0,338 & \\
\hline \multicolumn{6}{|c|}{ Intellectual Capital } \\
\hline Human Capital & 0,802 & & 0,6430 & 0,357 & $\mathrm{C}-\mathrm{R}=\mathbf{0 , 8 2 7}$ \\
\hline Structural Capital & 0,849 & 10,626 & 0,7207 & 0,279 & $V-E=0,616$ \\
\hline Relational Capital & 0,697 & 7,577 & 0,4851 & 0,515 & \\
\hline \multicolumn{6}{|c|}{ Bank's Performance } \\
\hline Funding & 0,865 & & & 0,252 & $\mathrm{C}-\mathrm{R}=\mathbf{0 , 9 1 1}$ \\
\hline Landing & 0,872 & 16,909 & 0,7481 & 0,240 & $V-E=0,673$ \\
\hline Earnings & 0,791 & 10,728 & 0,7601 & 0,375 & \\
\hline Operatinal efficiency & 0,768 & 12,720 & 0,6255 & 0,410 & \\
\hline Loyalty & 0,800 & 12,226 & 0,6400 & 0,360 & \\
\hline
\end{tabular}

Source: Appendix Output OutputLisrel 8.8

Latent Variable Knowledge Management. Results in the Table of Loding Results Factor Measurement and Latent Variables showed the presence factor $(\lambda)$ of the measurement variable (manifest) for the latent variable Knowledge management was good, above the average submission factor of 0.5 which was between $0.7-0.9$. The value obtained for each manifest variable was more than 1.96. The value of Construct Reliability variable Knowledge Management was above 0.7 that is 0.852 . These values indicated the latent variables that were formed,had a relatively high level and indicators that ultimately had a good suitability. Projection of Variance Extracted for Latent Knowledge Management variables was 0.592 . The value obtained at cut off $=0.5$ which showed the magnitude of variables included in the construct, that was formed (latent variable) was relatively high, theoretically could occur (latent variable) was precisely built from the indicator.

Latent Variable Intellectual capital. The results in the table above showed the loading factors of manifest variables for latent variables Intellectual capital was good, above the average loding factor of 0.5 , which ranges from 0.6 to 0.9 . The tcount obtained for each manifest variable was more than 1.96 so that it could be said that the manifest variables used were significant in measuring the variables of intellectual capital used. Value of Construct Reliability variable Intellectual capital above 0.7 is 0.827 . This value showed the latent variables which I had formed had a relatively high level of reliability and the indicators used in the latent variable have a good suitability. The results of the calculation of Variance Extracted for the latent variable intellectual capital was 0.616. Values obtained above the cut-off $=0.5$ which indicated the magnitude of the measurement variable which I had included in the construct that isI formed (latent variable) was relatively high, as a whole could be stated the construct formed (the latent variable of Intellectual Capital) had been appropriately constructed based on the indicator. 
Latent Variables of Bank Performance. The results in the table above showed that the loading factor of the manifest variable for the latent variable of the Bank's performance was good, above the average factor of 0.5 , which was between $0.7-0.9$. The tcount obtained for each manifest variable was more than 1.96 so that it could be said that the manifest variables that were used are meaningful in measuring the Bank Performance variables used. The Construct Reliability value of the Bank Performance variable was above 0.7, which was 0.911. This value showed that the latent variables which were formed had a relatively high level of reliability and the indicators used in the latent variables had good suitability. The result of the Variance Extracted calculation for latent Bank Performance variables was 0.673 . The value obtained above the cut-off $=0.5$ which showed the amount of manifest variables which I had included in the construct that I formed (latent variable) was relatively high, as a whole could be stated that the construct that I formed (latent variable Bank Performance) was appropriately constructed based on the indicator.

Research Hypothesis Testing. In this study there were four hypotheses tested, in detail the results of testing hypotheses are as follows:

Hypothesis 1 Test. Based on the results of the data processing using SEM-Lisrel, the tcount value of 5.0811 was greater than the critical value of 1.96. This means that the Knowledge Management path coefficient of intellectual capital of 0.5279 is significant, so hypothesis 1 is accepted. This means that Knowledge Management which was getting better would have an impact on the increase in good intellectual capital which was relatively large.

Hypothesis 2 Test. Based on the results of the data processing using SEM-Lisrel obtained tcount of 2, 62 was greater than the tkritic of 1.96. This meant that the coefficient of the Intellectual Capital path to the Bank's Performance of 0.2730 was significant, so hypothesis 2 was accepted. This meant that the better Intellectual Capital would have an impact on the increase in the Bank's performance which was quite large.

Hypothesis 3 Test. Based on the results of the data processing using SEM-Lisrel, the tcount value was 2.7812 greater than the critical 1.96. This means that the calculation results of the path coefficient for Knowledge Management variables on Bank Performance obtained at 0.2932 are significant, so hypothesis 3 was accepted. This meant that better Knowledge Management would have an impact on the relatively large increase in Bank Performance.

Hypothesis 4Test. Based on the results of the data processing using SEM-Lisrel, the tcount value was 2.3288 , which was greater than the 1.96 critical level so that it could be concluded that the fourth hypothesis was accepted. To examine the effect of Knowledge Management on Bank Performance with intellectual capital as an intervening variable, Sobel test is used (Kline, 2011). Indirectly through intellectual capital, Knowledge Management gave an influence of $0.5279 \times 0.2730 \times 100 \%=14.14 \%$ of the Bank's Performance. Meaning that Knowledge Management, which had higher effectiveness and was mediated by good intellectual capital, would have an impact on the Bank's performance improvement. 
Discussion.Influence of Knowledge Management on Intellectual Capital. It had been tested that knowledge management had a significant positive effect on the intellectual capital of branch offices of state-owned banks in West Java. This showed that the better the implementation of knowledge management by the branch offices of state-owned banks, the better the intellectual capital owned by the state-owned banks branch office. This meant that the process of creating knowledge from the start of the process of socialization, externalization, combination, to internalization to obtain the successful implementation of employee duties hadbeen carried out well or effectively by the branch offices of state-owned banks. When viewed from factor analysis, the combination dimension and internalization have the highest loading factor. This meant that in knowledge management, the combination and internalization dimensions were the dimensions that best reflected SECI's processes in the bank, so that these two dimensions were the most important. The combination process utilizing existing exploratory knowledge to be implemented into new explicit knowledge was more useful. For example, the combination process is carried out by a customer service when successfully handling a customer's complaint that cannot be handled through SOP. At that time he combined SOP with the psychology he read. Then he developed the method into a new form of SOP handling coplaint. In addition, the internalization process will run when the SOP handling coplaint is used to handle similar cases.

Both of these dimensions need to be prioritized to be developed in order to be able to produce intellectual capital including human capital, where knowledge of employee competencies can increase. The structural capital also increased both in number and value. Finally, the ability to serve the needs of customers well results in a stronger relationship with customers and prospective customers.

Conclusion This study supports the findings of several previous researchers. Rajesh defined knowledge management as an instrument to increase intellectual capital which ultimately guarantees future financial success. Knowledge management is planning, organizing, controlling people, processes and systems in an organization in order to ensure that related knowledge assets can be continuously improved and used effectively (Rajesh et. Al., 2011), so knowledge management has an influence on intellectual capital ( Rafiee et.al, 2015; Nazem, 2012; Daud and Yusof, 2011). The results of previous research are the same as the results of the authors' research that to increase intellectual capital that is effective and has added value requires the continuous application of knowledge management.

The Influence of Intellectual Capital on the Performance of Branch Offices of StateOwned Banks. It had been tested that intellectual capital had a significant positive effect on branch office performance. This meant that the better the intellectual capital owned by the state-owned bankbranch offices, the higher the performance of the state-owned bank branchoffices.

Based on factor analysis data, structural capital had the highest loading factor, meaning that structural capital was the dimension that best reflects the variables of intellectual capital so that this dimension became the most important dimension compared to other dimensions of intellectual capital variables. Structural capital owned by banks should be able to meet the needs of customers as their capital. For example SOP, IT, and service quality SOP. The application of the IT system is one of the long-term investment activities for banks. It should be the thing that must be taken into account by the bank. As an intermediary institution for the community, banks should become loyal "servants" by 
always realizing the forms of services by using existing structural capital, especially information technology. The use of Information Technology (IT) in banks is expected to facilitate banks and customers, such as the use of services such as ATMs, Phone Banking, Internet Banking, or SMS / m-Banking. Likewise with SOPs that are able to provide quality services so that a harmonious relationship with customers and potential customers will be stronger.

Thus, if a state-owned bank wants to be a bank that is able to compete in the ASEAN region, the bank should have the best structural capital, because with the structural capital and relations capital owned, the bank will be able to increase the growth in the amount of $\mathrm{TPF}$, the growth of credit, revenue growth, efficiency operational costs, and get customer loyalty.

The Conclusion of this study justified previous research. The results of the research by Onyekwelu et.al (2017) and Andreeva \& Garanina (2017) concluded that three dimensions of intellectual capital (human, structural, and customer / relational) that are interrelated, will have a positive influence on organizational performance. Highly competent human capital will be able to understand customer needs, and they will develop customer capital in maintaining their loyalty. Furthermore, human capital and customer capital will affect structural capital. Human capital, customer capital, and structural capital are the dimensions of intellectual capital that have a positive influence on business performance. Further intellectual capital can be defined as the economic value of the three categories of intangible assets of an organization which include human resources, organizational capital, and social capital collectively contributing to improving organizational performance (Al Musali, 2014; Gigante, 2013; Zehri, et. al. 2012). The three components of intellectual capital will have a significant influence on organizational performance provided there is a link between each component. The results of the author's research are in line with previous studies that there is a variable influence of intellectual capital on the performance variable.

The Influence of Knowledge Management on the Performance of Branch Offices of State-Owned Banks. It had been tested that knowledge management had significant positive effect on branch office performance. This meant that the better the implementation of knowledge management at the branch offices of state-owned banks, the higher the performance of the state-owned bank branch offices.

Based on the value of the loading factor obtained, the combination process and internalization process were the dimensions that best reflect the variables. For this process, this would be able to increase the dimensions of collection and distribution of funds as the highest loading factor in performance variables. Back to the example above, that a customer service capable of handling a number of cases of customer complaints as a result of a combination and internalization process, then automatically customer loyalty will increase, because what the customer needs can be met by the customer service. In addition Knowledge Management is a process that transforms individual knowledge into organizational knowledge. When knowledge is used to create innovative products that can generate income and profits or when management strategies are aligned with business strategies, organizational performance will emerge.

State-owned bank branch offices facilitate knowledge sharing activities among employees so that a lot of new knowledge is created from these activities and storing new, more systematic knowledge to be redistributed through appropriate methods to branch 
office members will improve the performance of state bank branch offices in terms of achieving targets in the short term that supports the long-term target of the performance of the state-owned banks. With branch office knowledge management, it is more efficient in managing various knowledge that is spread in various places and dimensions so that it reduces the level of operational costs that should be incurred.

Knowledge management can enhance the bank's ability to create and expand knowledge regarding products, customers and managerial resources throughout the business process. Product design, expertise can be shared throughout the business process so as to reduce development costs, accelerate the development of new products and support a rapid response to new market opportunities so as to convince customers to remain and be more loyal.

The conclusion of this studywasin line with the conclusions of previous studies. Nonaka (1995) using the SECI matrix as a dimension of knowledge management concluded that the success of many companies depends on their ability to create new organizational knowledge. Wang (2011) from his research results concluded that organizational performance would increase through learning with a system that integrates people, processes, and technology.

Knowledge management is a process that transforms individual knowledge into organizational knowledge (Rasula, 2012), so that acquisition, application of knowledge is significantly related to organizational performance (Mills and Smith, 2011). Knowledge management will lead to the development of new ideas, new products, as well as new ways to improve organizational performance (Mahapa, 2013). From the results of the author's research and the results of several previous studies it can be concluded that knowledge management will be able to improve the performance of an organization.

The Role of Knowledge Management in Improving the Performance of Branch
Offices of State-Owned Banksin West Java through Intellectual Capital. It had been tested that Knowledge Management which was increasingly effective and mediated by intellectual capital would have an impact on an increase in Bank Performance. That is, the role of intellectual capital increases the influence of the influence of knowledge management on performance. From some of the explanations above, branch offices that carry out continuous knowledge creation enable to have good intellectual capital, starting from the increasing HR competencies that can increase the growth of third party funds, lending which will ultimately increase revenue. The better the structural capital that a bank has, such as the standard operating procedure strategy, will answer all customer needs so that the number of complaints becomes small and they will be more loyal. An improved service quality strategy will make relationships with potential customers and potential customers more harmonious. The power of knowledge management allows customers to access self-service, commonly called e-service or online selt help. With knowledge management, IT capital is more developed. Because with knowledge management the bank knows the importance of IT in improving services for customers. Customers prefer banks that can quickly and easily find or provide information needed by customers accurately and they will eventually be happy and loyal to banks that always provide whatever their needs in banking. In addition, self-service can make companies reduce operational costs and streamline the organization so that they can use the right resources in a more dynamic organization. 
The conclusion of the author's research was not different from previous studies. Salemi et.al (2014) concluded that knowledge management had an indirect effect on business performance in the banking industry in Iran. Knowledge management had a direct influence on intellectual capital and intellectual capital directly influences business performance. Intellectual capital acts as a mediator between knowledge management processes affecting performance. The knowledge management process alone had made a positive contribution to performance, but the inclusion of intellectual capital as a mediator helped improve performance. Thus, from the results of this study and several previous studies can be concluded that in order to improve performance, banks need to focus on the knowledge management process and recognize the importance of intellectual capital as a strategic organizational asset.

\section{CLOSING}

Conclusion. Based on the results of the hypothesis testing concluded that knowledge management had a positive effect on intellectual capital as well as on the performance of state-owned bank branch offices in West Java Province. Intellectual capital also had a positive effect on branch office performance. This showed that the high and low performance of branch offices depends on the good and bad of the intellectual capital owned by the branch office generated by the effective application of knowledge management. Intellectual capital exists as an intervening variable, so the influence of knowledge management on branch offices' performance would be greater, namely the direct influence of knowledge management on branch office performance plus indirect influence through intellectual capital.

So, structural capital owned by a bank is competent human capital, for example in the field of credit analysts, structural capital such as the establishment of SOPs and service quality strategies, for example relational capital, the bank's harmonious relationship with customers (prospective customers) will be able to improve branch office performance. It is said that intellectual capital can mediate the influence of knowledge management on performance. Knowledge management that is directed to increase the value of intellectual capital will further strengthen the influence of knowledge management on the performance of branch offices of state-owned banks in West Java Province, so that state-owned banks are better able to compete in ASEAN.

Suggestion. By having the influence of knowledge management on branch offices both directly and indirectly, the branch office can do:

a. The first way (short-term advice) is to increase its direct influence. Knowledge management activities at the branch office are directed directly at the practical application. My advice is that the head office continues to provide sophisticated, systematic programs for use in branch offices as a means of knowledge management so that new knowledge is always created continuously. For example, the Online Course Ware program is a program for organizations in managing knowledge for organizations and their members. Another suggestion is that management requires its employees to do learning by doing, namely applying new knowledge when working (internalization) for example in priority activities such as increasing customer loyalty and suppressing inefficiencies.

b. The second way (long-term advice) is to increase its indirect influence. Branch office management must set up a better knowledge management process, by giving 
employees time and space to be able to get used to writing experiences and ideas on the accounts that have been provided. The written results must be easily accessed and understood by other employees so that they become new knowledge for themselves and the company. If this process is carried out continuously, the branch office's intellectual capital will increase. This is a long-term strategy so that state-owned banks can create superior performance by providing the best services for customers and prospective customers so that over time state-owned banks can win competition at the regional and global levels.

\section{REFERENCES}

Al-Musali, Mahfoudh Abdul Karem, Ku Nor Izah Ku Ismail. (2014). "Intellectual capital and its effect on financial performance of banks: Evidence from Saudi Arabia". Procedia - Social and Behavioral Sciences, 164 (20), 201 - 207

Andreeva ., Garanina . (2017). "Intellectual Capital and Its Impact on the Financial Performance of Russian Manufacturing Companies". Foresight and STI Governance, 11 (1), 31-40. DOI: 10.17323/2500-2597.2017.1.31.40

BadanPusatStatistikmelaluiwww.bps.go.id.(2014)

Becerra Irma, Fernandez, and Rajiv Sabherwal.(2010).KnowledegeMangement System and Process. New York: ME. Sharpe.

Bontis, Nick, Chua, W. and S. Richardson.(2000). "Intellectual capital and business performance in Malaysian industries". Journal of Intellectual Capital, 1 (1), 85100

Daud, S. \&Yusoff, W.F.W. (2011)."How intellectual capital mediates the relationship between knowledge management processes and organizational performance". African Journal of Business.

Gigante, Gimede. (2013)."Intellectual Capital and Bank Performance in Europe". Accounting and Finance Research, 2 (4). www.sciedu.ca/afr

Gonzalez, R. V. D., Martins, M. F., \& Toledo, J. C. (2014). "Mapping the organizational factors that support knowledge management in the Brazilian automotive industry".Journal of Knowledge Management, 18(1), 611-630.

Hair, Black, Babin, Anderson, danTathan.(2006).Multivariate Data Analysis-Sixth Edition.Pearson Prentice Hall. New Jersey.

Hughes, Joseph P. and Loretta J. Mester. (2013).Measuring the Performance of Banks: Theory, Practice, Evidence, and Some Policy Implications. Prepared for the Oxford Handbook of Banking, 2nd edition

Kline, R. B. (2011) Principles and Practices of Structural Equation Modeling. New York. Third Edition.The Guilford Press.

Mahapa,Mildred. (2013).“Impact of Knowledge Management Strategies on OrganizationalPerformance in the Hospitality Industry of Zimbabwe". Public Administration Research; 2 (1), Published by Canadian Center of Science and Education

Mills, A., \& Smith T. (2011).“Knowledge management and organizational performance: a decomposed view".Journal of Knowledge Management, 15(1), 156-171.

Nazem, Fattah. (2012).The Compilation of a Structural Model for Intellectual Capital Based on the Knowledge Management in Universities Department of Education.RoudehenBranch.Islamic Azad University, Roudehen, Iran 
Nonaka I. \& Takeuchi H. (1995).The Knowledge Creation Campany: How Japanese Companies Create The Dynamic of Innovation. New York: Oxford University Press.

Onyekwelu, Uche Lucy, Okoh, Johnson Ifeanyi \& Iyidiobi, F.C. (2017)."Effect of Intellectual Capital on Financial Performance of Banks in Nigeria". European Journal of Accounting, Auditing and Finance Research, 5 (2), 28-57, February.

Pasher Edna \& Ronen Tuvya.(2011).The Complete Guide to Knowledge Management : a Strategic PIan to Leverage your Campany's Intellectual Capital . USA: Wiley.

Petria, Nicolae, BogdanCapraru, IulianIhnatov. (2015). Determinants of banks' profitability: evidence from EU 27 bankingsystems Procedia Economics and Finance. $518-524$

Rafee, Elnaz pour, ShohreMasjedi, PeymanAkhavan. (2015).Exploring the Relationship between Knowledge Management andIntellectual Capital: An Iranian University Case Study.International Journal of Management Academy, 3 (1), 7-15

Rasula, Jelena ;VesnaBosiljVuksic; Mojca Indihar Stemb erg er. (2012) The Impact of Knowledge Management on Organizational Performance. Economic and Business Review.

Rajesh, R., Pugazhendhi, S. and Ganesh, K. (2011).Towards taxonomy architecture of knowledge management for third party logistics service provider.Benchmarking: An International Journal, 18 (1), 42-68.

Salemi, ImanLangeroodi. (2014). The Effect of The Knowledge Management and Intellectual Capital on Organizational Performance in State Banks of Rasht. Indian Journal of Fundamental and Applied Life Sciences.ISSN: 2231- 6345 (Online)4 (S1) April-June, pp. 1393-1404

Sekaran, U. (2006).Research Methods for Business, a Skill Building Approach.4th ed.John Wiley \& Sons, Inc. NY.P 32.Terjemahan

Wang, W. (2011).Examining the use of knowledge management during issue management. Management Research Review, 34 (4) (forthcoming).

Zehri Chokri, Asma Abdelbaki, Najla Bouabdellah. (2012)."How Intellectual Capital efects a Firm's Performance?",Australian Journal of Business and Management Research. 2 (08), 24-31, November-2012. ISSN: 1839 - 0846 